Selcuk Journal of Agriculture and Food Sciences

http://sjafs.selcuk.edu.tr/sjafs/index

Research Article
SJAFS

(2020) 34 (3), 207-213

e-ISSN: $2458-8377$

DOI:10.15316/SJAFS.2020.218

\title{
Environmental Mitigation Through Irrigation Management in Sugar Beet Production
}

\begin{tabular}{|c|c|}
\hline ARTICLE INFO & ABSTRACT \\
\hline $\begin{array}{l}\text { Article history: } \\
\text { Received date: } 02.10 .2020 \\
\text { Accepted date: } 05.11 .2020\end{array}$ & $\begin{array}{l}\text { This study assesses the greenhouse gases (GHG) emissions of sugar beet pro- } \\
\text { duction under different irrigation and nitrogen fertilizing strategies. This man- } \\
\text { uscript is an evaluation of the production inputs used in a research carried } \\
\text { previous on sugar beet and its conversion into GHG emissions equivalent. This }\end{array}$ \\
\hline $\begin{array}{l}\text { Edited by: } \\
\text { Duran YAVUZ; Selcuk University, } \\
\text { Turkey }\end{array}$ & $\begin{array}{l}\text { paper evaluates the potential for environmental mitigation, including the reduc- } \\
\text { tion of total GHG emissions from agricultural inputs in sugar beet production } \\
\text { by managing irrigation and nitrogen fertilizing. In this context, the nine treat- } \\
\text { ments based on three different irrigations (full irrigation, conventional deficit }\end{array}$ \\
\hline $\begin{array}{l}\text { Keywords: } \\
\text { Sugarbeet } \\
\text { Greenhouse gas (GHG) emissions } \\
\text { Irrigation } \\
\text { Environmental pollution }\end{array}$ & $\begin{array}{l}\text { gies (full nitrogen, partial deficit nitrogen, moderate deficit nitrogen) were } \\
\text { assessed. The results of evaluation showed that DI-N } \mathrm{N}_{1} \text { strategy can reduce } \\
\text { irrigation water and nitrogen use up to } 25 \% \text { compared to control treatment (FI- } \\
\mathrm{N} \text { ). In addition, this strategy saved } 25 \% \text { of electricity consumption use for } \\
\text { irrigation. The analyse of pollution in this study led to very important findings: } \\
\text { more environment-friendly irrigation and fertilization practices by using less } \\
\text { water and nitrogen have a considerable potential for environmental mitigation } \\
\text { in sugar beet production. }\end{array}$ \\
\hline
\end{tabular}

\section{Introduction}

Agriculture is both an energy user and energy supplier system. When using solar energy to produce biomass, plants capture atmospheric carbon dioxide $\left(\mathrm{CO}_{2}\right)$ as their main source of carbon. Agriculture supplies energy by growing crops that convert solar energy into biomass, which in turn supplies energy to human beings and animals. On the other hand, agriculture uses large quantities of energy inputs such as diesel fuel, electricity, fertilizer, plant protection, chemicals, machinery and human labor. Besides the energy consumption, greenhouse gases (GHG) emission and global warming potential (GWP) issues are also critical in the agricultural production systems in recent twenty years (Khoshnevisan et al. 2013). Because, greenhouse gases produced as a result of agricultural activities, enhance the natural greenhouse effect. However agricultural crops bind $\mathrm{CO}_{2}$ from the air via the photosynthesis process, but crop production on farmer's field is also a source of the GHG emissions. Also, for each crop the $\mathrm{CO}_{2}$ fixation is much higher than the $\mathrm{CO}_{2}$ emissions associated with the production of the crops (Küsters 1999).

\footnotetext{
*Corresponding author email: rtopak@selcuk.edu.tr
}

Today the agriculture sector is one of main contributors for energy consumption and GHG emissions (Barker et al. 2009; Devi et al. 2009). Each year, agriculture emits $10-12 \%$ of the total estimated GHG emissions (Niggli et al. 2009). Studies of the direct energy use of on-farm operations suggest that grounwater pumping for irrigation is one of the highest energy consumption processes (Lal 2004; Mushtaq et al. 2009; Qiu et al. 2018). On a global scale, agricultural irrigation consumes approximately $70 \%$ of the world's fresh water supply; $90 \%$ of this irrigation takes place in arid and semi-arid areas (Viala 2008). Water resources are usually scarce in these areas and irrigation often requires electric energy to pump or divert water. Therefore, agricultural irrigation consumes both water and energy (Jimenez-Bello et al. 2015). Irrigation is important for achieving high yields in arid and semiarid regions. Globally, $17 \%$ of irrigated cropland leads to $40 \%$ of the total production (Postel 1999). Yet, irrigation is a very carbon intensive practice. Irrigated agriculture around the world relies heavily on energy resources to extract freshwater and to convey it to application sites. This is especially the case in arid and semi-arid regions, where large amounts of irrigation water are required to sustain crop production. As a result, the availability and cost of energy are among major factors influencing the economic viability of irrigated agriculture in these regions. In addition, ener- 
gy consumption for irrigation has major environmental consequences, mainly due to the emission of GHG (Khan et al. 2014; Pradeleix et al. 2015; Handa et al. 2019).

Turkey produces about 18 million ton /year sugar beet root from 320000 ha cultivation land area. Sugar beet is grown throughout Turkey under irrigated conditions. Konya basin produces about $42 \%$ of total sugar beet production in Turkey. Sugar beet is a major commercial field crop in this region which is the largest producer of Turkey (TÜİK 2020). The Konya basin, Middle Anatolian region in Turkey, lies within a semiarid area with annual rainfall ranging from 280 to 500 $\mathrm{mm}$ (average $323 \mathrm{~mm}$ ), and is one of the most important agricultural and agro-industrial regions. Water loss by evapotranspiration is very high during the growing season in the basin. However, available water resources of Konya basin are fairly scant. Thus, water is an essential component and the single most important factor in limiting crop production in the region (Topak et al. 2008). Irrigation water for crops is obtained mainly from ground water resources (Göçmez and İşçioğlu 2004) and there are approximately 100 000 deep wells in the basin (WWF 2014). This study is undertaken for making realistic assessment of GHG emissions from groundwater irrigated sugar beet production in Konya region in Turkey and evaluate the impact of irrigation management strategies for reducing the GHG emissions.

\section{Materials and Methods}

This study is used the data regarding the production inputs and yields of the field treatment of a project, which carried out on sugar beet by Topak et al (2014) in Konya conditions. In the article, we evaluated the effects of irrigation techniques and nitrogen doses on GHG emissions of sugar beet production, which is not within the scope of the project. In this context, the treatments are defined based on three different irrigation techniques and three nitrogen amounts as follows:

FI-N: Full irrigation + full nitrogen.

FI-N ${ }_{1}$ : Full irrigation $+75 \%$ of full nitrogen.

FI- $\mathrm{N}_{2}$ : Full irrigation $+50 \%$ of full nitrogen.

DI-N: $75 \%$ of full irrigation + full nitrogen. (DI: Conventional deficit irrigation)
DI-N $\mathrm{N}_{1}: 75 \%$ of full irrigation $+75 \%$ of full nitrogen.

DI-N $2: 75 \%$ of full irrigation $+50 \%$ of full nitrogen.

PRD-N: $50 \%$ of full irrigation + full nitrogen. (PRD: Partial root drying irrigation)

PRD-N $\mathrm{N}_{1}: 50 \%$ of full irrigation $+75 \%$ of full nitrogen. PRD- $\mathrm{N}_{2}: 50 \%$ of full irrigation $+50 \%$ of full nitrogen.

In the mentioned project, irrigation water was taken from the deep well adjacent to the trial field with a flow rate of $75 \mathrm{~m}^{3} \mathrm{~h}^{-1}$. The field experiment was irrigated by drip irrigation system. Irrigation was applied when $35-40 \%$ of the available soil moisture was consumed in the $0.90-\mathrm{m}$ root zone in the FI treatment during the irrigation periods. The FI treatment was designated to receive $100 \%$ replenishment of soil water depletion. Depletion was defined as the difference between the depth of water held in the root zone at field capacity and the depth of water actually held in the root zone at the time of an irrigation decision. Fertilizers were applied on the basis of soil analysis. In soil samples, soil nitrogen before sowing was determined as $57.5 \mathrm{~kg} \mathrm{ha}^{-1}$. Diammonium phosphate fertilizer $(18 \%$ $\mathrm{N}, 46 \% \mathrm{P}_{2} \mathrm{O}_{5}$ ) was applied to the soil at a rate of $200 \mathrm{~kg}$ $\mathrm{ha}^{-1}$ prior to seeding. The remaining nitrogen amounts (N: $126.5 ; \mathrm{N} 1: 85.9 ; \mathrm{N} 2: 45.3 \mathrm{kgha}^{-1}$ ) for the treatments were applied in the form of a urea fertilizer $(46 \% \mathrm{~N})$ in four equal parts during the first four irrigation cycles using a fertigation system. Total irrigation water, nitrogen amounts and root yields related to the treatments are given in Table 1. Production inputs and quantities related to the treatments examined are given in Table 2 and Table 3. Except for beet harvester, the input data were obtained from mentioned project records. Information associated with beet harvester was taken from farmers.

Since 1990, in Konya basin, over-exploitation from the groundwater resources is present. Long-term groundwater over-exploitation has led to a continuous decline in the groundwater depth in Konya basin and the groundwater table in the plains has decreased as well as notable. This decline of the groundwater table has led to an increase in energy consumption for groundwater exploitation. Therefore, electricity consumption per $\mathrm{m}^{3}$ of groundwater has been revised according to today's conditions and taken into account as $0.5 \mathrm{kWh}$ per $\mathrm{m}^{3} \quad$ water.

Table 1

Yield values with the amounts of nitrogen and water applied to treatments

\begin{tabular}{lccccccc}
\hline Treatments & $\begin{array}{c}\text { Nitrogen } \\
\left(\mathrm{kg} \mathrm{ha}^{-1}\right)\end{array}$ & $\begin{array}{c}\text { Irrigation } \\
\text { Water } \\
(\mathrm{mm})\end{array}$ & $\begin{array}{c}\text { Crop water } \\
\text { use } \\
(\mathrm{mm})\end{array}$ & $\begin{array}{c}\text { FRY } \\
\left(\mathrm{kg} \mathrm{ha}^{-1}\right)\end{array}$ & $\begin{array}{c}\text { SRY } \\
\left(\mathrm{kg} \mathrm{ha}^{-1}\right)\end{array}$ & $\begin{array}{c}\text { RDMY } \\
\left(\mathrm{kg} \mathrm{ha}^{-1}\right)\end{array}$ & $\begin{array}{c}\text { SY } \\
\left(\mathrm{kg} \mathrm{ha}^{-1}\right)\end{array}$ \\
\hline FI-N & 162.5 & 851.1 & 961.8 & 93433 & 110951 & 21075 & 17803 \\
FI-N $_{1}$ & 121.87 & 851.1 & 961.8 & 88715 & 107678 & 20450 & 17245 \\
FI-N $_{2}$ & 81.25 & 851.1 & 961.8 & 88838 & 108660 & 20411 & 17405 \\
DI $-\mathrm{N}$ & 162.5 & 643.3 & 784.2 & 80818 & 101628 & 19344 & 16253 \\
\hline
\end{tabular}


Topak and Kalender / Selcuk J Agr Food Sci, (2020) 34 (3), 207-213

Table 1

Yield values with the amounts of nitrogen and water applied to treatments

\begin{tabular}{lccccccc}
\hline DI-N & 121.87 & 643.3 & 784.2 & 81653 & 105077 & 19915 & 16820 \\
DI-N $_{2}$ & 81.25 & 643.3 & 784.2 & 79435 & 100187 & 18803 & 16028 \\
PRD-N & 162.5 & 435.6 & 588.5 & 66905 & 88733 & 16937 & 14210 \\
PRD-N $_{1}$ & 121.87 & 435.6 & 588.5 & 65102 & 86870 & 16688 & 13913 \\
PRD-N $_{2}$ & 81.25 & 435.6 & 588.5 & 66710 & 89266 & 16954 & 14295 \\
\hline
\end{tabular}

FRY: Fresh root yield; RDMY: Root dry matter yield; SY: Sugar yield; SRY (Standardized Root Yield): root yield calculated according to the standard $16 \%$ sugar ratio.

Table 2

The inputs of sugarbeet production

\begin{tabular}{|c|c|c|c|c|c|c|c|c|}
\hline \multirow[t]{2}{*}{ Treatments } & \multicolumn{8}{|c|}{ İnputs } \\
\hline & $\begin{array}{c}\text { Electricity } \\
\left(\mathrm{kWh} \mathrm{ha}^{-}\right. \\
1)\end{array}$ & $\begin{array}{l}\text { Diesel } \\
\text { fuel } \\
\left(\mathrm{L} \mathrm{ha}^{-}\right. \\
1)\end{array}$ & $\begin{array}{l}\text { Nitrogen } \\
\left(\mathrm{kg} \mathrm{ha}^{-1}\right)\end{array}$ & $\begin{array}{c}\text { Phosphorus } \\
\left(\mathrm{P}_{2} \mathrm{O}_{5}\right) \\
\left(\mathrm{kg} \mathrm{ha}^{-1}\right)\end{array}$ & $\begin{array}{c}\text { Potassium } \\
\left(\mathrm{K}_{2} \mathrm{O}\right) \\
\left(\mathrm{kg} \mathrm{ha}^{-1}\right)\end{array}$ & $\begin{array}{c}\text { Human } \\
\text { Labor } \\
\left(\mathrm{h} \mathrm{ha}^{-1}\right)\end{array}$ & $\begin{array}{c}\text { Drip sys- } \\
\text { tem } \\
(\Phi 110 \\
\mathrm{mm})^{*} \\
\left(\mathrm{~m} \mathrm{ha}^{-1}\right)\end{array}$ & $\begin{array}{l}\text { Drip system } \\
\quad(\Phi 16 \\
\mathrm{mm})^{* *} \\
\left(\mathrm{~m} \mathrm{ha}^{-1}\right)\end{array}$ \\
\hline FI-N & 4255.5 & 105 & 162.5 & 92 & 70 & 240 & 120 & 22220 \\
\hline FI-N 1 & 4255.5 & 105 & 121.87 & 92 & 70 & 240 & 120 & 22220 \\
\hline FI-N 2 & 4255.5 & 105 & 81.25 & 92 & 70 & 240 & 120 & 22220 \\
\hline $\mathrm{DI}-\mathrm{N}$ & 3216.5 & 105 & 162.5 & 92 & 70 & 240 & 120 & 22220 \\
\hline DI-N ${ }_{1}$ & 3216.5 & 105 & 121.87 & 92 & 70 & 240 & 120 & 22220 \\
\hline DI-N ${ }_{2}$ & 3216.5 & 105 & 81.25 & 92 & 70 & 240 & 120 & 22220 \\
\hline PRD-N & 2178 & 105 & 162.5 & 92 & 70 & 240 & 120 & 22220 \\
\hline PRD-N ${ }_{1}$ & 2178 & 105 & 121.87 & 92 & 70 & 240 & 120 & 22220 \\
\hline PRD-N ${ }_{2}$ & 2178 & 105 & 81.25 & 92 & 70 & 240 & 120 & 22220 \\
\hline
\end{tabular}

*: Life 15 years; **: Life 7 years

Table 3

The energy input from agricultural machinery

\begin{tabular}{lcccccc}
\hline Agricultural machinery & $\begin{array}{c}\text { Machine } \\
\text { Weight } \\
(\mathrm{kg})\end{array}$ & $\begin{array}{c}\text { Energy } \\
\text { equivalent } \\
\left(\mathrm{MJ} \mathrm{kg}^{-1}\right)\end{array}$ & $\begin{array}{c}\text { Useful life } \\
(\mathrm{h})\end{array}$ & $\begin{array}{c}\text { Energy } \\
\text { equivelent } \\
\left(\mathrm{MJ} \mathrm{h}^{-1}\right)\end{array}$ & $\begin{array}{c}\text { Working time } \\
\left.(\mathrm{h} \mathrm{ha})^{-1}\right)\end{array}$ & $\begin{array}{c}\text { Machine } \\
\text { energy } \\
\left(\mathrm{MJ} \mathrm{ha}^{-1}\right)\end{array}$ \\
\hline Beet harvester (6 rows) & 24000 & $71.38^{*}$ & 12000 & 142.8 & 2 & 285.5 \\
Tractor & 3340 & $71.38^{*}$ & $16000^{* * *}$ & 14.9 & 8 & 117.7 \\
Plow & 350 & $49.35^{* *}$ & $2000^{* * *}$ & 8.64 & 2.5 & 21.6 \\
Cultivator & 560 & $49.35^{* *}$ & $2000^{* * *}$ & 13.8 & 1 & 9.87 \\
Rotatil & 700 & $49.35^{* *}$ & $1500^{* * *}$ & 23.03 & 1.2 & 27.64 \\
Fertilizer Spreader & 100 & $49.35^{* *}$ & $1200^{* * *}$ & 4.94 & 0.3 & 1.0 \\
Sowing machine & 530 & $49.35^{* *}$ & $1500^{* * *}$ & 17.44 & 2 & 34.88 \\
Row crop cultivator & 430 & $49.35^{* *}$ & $2000^{* * *}$ & 10.6 & 1 & 6.17 \\
Total Machine Energy $\left(\mathrm{MJ} \mathrm{ha}^{1}\right)$ & & & & & 512.79 \\
\hline
\end{tabular}

*Acaroğlu ve Aksoy (2005); ** Hacıseferoğulları ve Acaroğlu (2015); ***ASAE (1999).

The required energy in farm machinery manufacturing was calculated as:

$\mathrm{E}_{\mathrm{M}}=\left(\mathrm{W}_{\mathrm{M}} / \mathrm{L}_{\mathrm{M}}\right) \times \mathrm{E} \times \mathrm{T}\left(\mathrm{MJ} \mathrm{ha}^{-1}\right)$

Where EM is the energy of the mobile and stationary mechanical power per unit area $\left(\mathrm{MJ} \mathrm{ha}^{-1}\right) ; \mathrm{W}_{\mathrm{M}}$ is the weight of mechanical power $(\mathrm{kg}) ; \mathrm{L}_{\mathrm{M}}$ is the economic life of the mechanical power $(\mathrm{h})$; $\mathrm{E}$ is the energy coefficient $\left(\mathrm{MJ} \mathrm{kg}^{-1}\right)$; and $\mathrm{T}$ is the work hours per unit area per year $\left(\mathrm{h} \mathrm{ha}^{-1}\right)$.

\subsection{GHG emissions assessment}

To determine the impact of irrigation level and nitrogen doses on environmental pollution from sugarbeet production, an assessment of GHG emissions was performed. The total GHG emissions for different treatments was obtained by calculating the emissions separately for input as fuel, electricity, human power, agricultural machinery, fertilizers, and drip system. Taking into account the different units of measurement, the GHG emissions for the total production inputs were calculated in a unified $\mathrm{CO}_{2}$ eq system using the conversion equivalents presented in Table 4.

Total GHG per hectare emissions is computed as: $\mathrm{GHG}_{\mathrm{T}}=\mathrm{E} \times \mathrm{EF}_{1}+\mathrm{D} \times \mathrm{EF}_{2}+\mathrm{F} \times \mathrm{EF}_{3}+\mathrm{M} \times \mathrm{EF}_{4}+\mathrm{DS} \times \mathrm{EF}_{5}+\mathrm{HP} \times \mathrm{EF}_{6}$ 
where:

$\mathrm{GHG}_{\mathrm{T}}$ - total GHG emissions for irrigated sugarbeet production $\left(\mathrm{kg} \mathrm{CO}_{2} \mathrm{eq} \mathrm{ha}^{-1}\right)$,

$\mathrm{E}$ - electricity consumption for irrigation $\left(\mathrm{kWh} \mathrm{ha}^{-1}\right)$, $\mathrm{EF}_{1}-$ emission factor for electricity $\left(\mathrm{kg} \mathrm{CO}_{2} \mathrm{eq} \mathrm{kWh}^{-1}\right)$, $\mathrm{D}$ - diesel fuel consumption for field works $\left(\mathrm{L} \mathrm{ha}^{-1}\right)$, $\mathrm{EF}_{2}$ - emission factor for diesel fuel $\left(\mathrm{kg} \mathrm{CO}_{2} \mathrm{eq} \mathrm{L}^{-1}\right)$, $\mathrm{F}-$ amount of fertilizer applied $\left(\mathrm{kg} \mathrm{ha}^{-1}\right)$,
$\mathrm{EF}_{3}-$ emission factor for fertilizers $\left(\mathrm{kg} \mathrm{CO}_{2} \mathrm{eq} \mathrm{kg}^{-1}\right)$,
$\mathrm{M}$ - input energy for machinery use ( $\left.\mathrm{MJ} \mathrm{ha}^{-1}\right)$,
$\mathrm{EF}_{4}-$ emission factor for machinery $\left(\mathrm{kg} \mathrm{CO}_{2} \mathrm{eq} \mathrm{MJ}^{-1}\right)$,
DS - drip irrigation system for irrigation $\left(\mathrm{m} \mathrm{ha}^{-1}\right)$,
$\mathrm{EF}_{5}-$ emission factor for drip system $\left(\mathrm{kg} \mathrm{CO}_{2} \mathrm{eq} \mathrm{m}^{-1}\right)$,
$\mathrm{HP}$ - human power for hoeing $\left(\mathrm{h} \mathrm{ha}^{-1}\right)$,
$\mathrm{EF}_{6}-$ emission factor for human labor $\left(\mathrm{kg} \mathrm{CO}_{2} \mathrm{eq} \mathrm{h}^{-1}\right)$.

Table 4

GHG emission equivalent values of agricultural inputs

\begin{tabular}{lll}
\hline Inputs of production & \multicolumn{1}{c}{ Emission factor } & \multicolumn{1}{c}{ References } \\
\hline Electricity & $0.55 \mathrm{~kg} \mathrm{CO}_{2} \mathrm{eq} \mathrm{kWh}^{-1}$ & Dulkadiroğlu (2018) \\
Diesel fuel & $2.76 \mathrm{~kg} \mathrm{CO}_{2} \mathrm{eq} \mathrm{L}^{-1}$ & Dyer and Desjardins (2003) \\
Human power & $0.7 \mathrm{~kg} \mathrm{CO}_{2} \mathrm{eq} \mathrm{h}^{-1}$ & Nguyen and Hermansen $(2012)$ \\
Nitrogen & $7.759 \mathrm{~kg} \mathrm{CO}_{2} \mathrm{eq} \mathrm{kg}^{-1}$ & Chen et al. (2015) \\
$\mathrm{P}_{2} \mathrm{O}_{5}$ & $2.332 \mathrm{~kg} \mathrm{CO}_{2} \mathrm{eq} \mathrm{kg}^{-1}$ & Chen et al. (2015) \\
$\mathrm{K}_{2} \mathrm{O}$ & $0.660 \mathrm{~kg} \mathrm{CO}_{2} \mathrm{eq} \mathrm{kg}^{-1}$ & Chen et al. (2015) \\
Machinery & $0.071 \mathrm{~kg} \mathrm{CO}_{2} \mathrm{eq} \mathrm{MJ}^{-1}$ & Dyer and Desjardins (2006) \\
Polyethylene (PE) production & $2.51 \mathrm{~kg} \mathrm{CO}_{2} \mathrm{eq} \mathrm{kg}^{-1}$ & Bai et al (2006) \\
$\mathrm{PE} \Phi 110$ mm tube & $3.56 \mathrm{~kg} \mathrm{CO}_{2} \mathrm{eq} \mathrm{m}^{-1}$ & Calculated \\
$\mathrm{PE} \Phi 16$ mm tube & $0.114 \mathrm{~kg} \mathrm{CO}_{2} \mathrm{eq} \mathrm{m}^{-1}$ & Calculated \\
Output & & \\
Beet root (Dry matter) & $0.45 \mathrm{~kg} \mathrm{C} \mathrm{eq} \mathrm{kg}^{-1}$ & Epstein ve Bloom (2005);Bolinder et \\
& & al(2007); Sánchez-Sastre et al (2018) \\
\hline
\end{tabular}

Due to the GHG emissions is based on carbon dioxide equivalent, to determine the carbon content this amount should be multiplied on ratio of carbon to carbon dioxide that it is $12 / 44$. Moreover, for treatments, carbon (C) yield in root biomass was determined. The carbon yields of treatments per hectare is calculated as follows:

$\mathrm{Y}_{\mathrm{C}}=\mathrm{RDMY} \times \mathrm{C}$

where:

$\mathrm{Y}_{\mathrm{C}}$ - carbon yield beet roots $\left(\mathrm{kg} \mathrm{ha}^{-1}\right)$,

$\mathrm{C}$ - carbon content beet roots $(\%)$.

In order to show the results of GHG emissions, two functional units were chosen: 1 tone of product (root and sugar) and 1 ha of farmland. Therefore, specific GHG emissions $\left(\mathrm{kg} \mathrm{CO}_{2} \mathrm{eq} \mathrm{t}^{-1}\right)$ and areal GHG emissions $\left(\mathrm{kg} \mathrm{CO}_{2} \mathrm{eq} \mathrm{ha}^{-1}\right)$ were computed.

\section{Results and Discussion}

Table 5 displays the estimates of GHG emissions for different inputs used in sugarbeet production. They were calculated from the farming inputs detailed in Table 2 and Table 3 and by applying the emissions factors presented in Table 4. The GHG emissions of sugarbeet production varied under different irrigation techniques and nitrogen doses, and both root yield and GHG emissions decreased as the irrigation and nitrogen amount decreased (Table 6). Application of the deficit irrigation and reducing the nitrogen amount had a positive effect on environmental pollution based on decreasing GHG emissions. The comparison of different irrigation and nitrogen strategies in sugarbeet production showed that the highest GHG emissions (4746.6 kg CO $\mathrm{keq} \mathrm{ha}^{-1}$ ) was in the control treatment (FI-N). The lowest GHG emissions (2973 kg $\mathrm{CO}_{2}$ eq ha ${ }^{-1}$ ) was observed under the PRD technique when $\% 50$ nitrogen deficit was used. Compared to con-

trol treatment $(\mathrm{FI}-\mathrm{N})$, the DI-N $\mathrm{N}_{1}$ treatment decreased the standardized root yield by only $5.0 \%$. On the other hand, the GHG emissions per unit of area from DI-N treatment was decreased by $18.7 \%$, when compared to the FI-N treatment.

The results indicated that the main component of GHG emissions was electricity for irrigation. An analysis of the impact of sugarbeet cultivation on environmental pollution showed that the greatest proportion of GHG emissions was related to electricity for irrigation (from $33.2 \%$ under PRD-N to $57 \%$ under FI- $\mathrm{N}_{2}$ ) and nitrogen (from $15.3 \%$ under FI-N $\mathrm{N}_{2}$ to $42.4 \%$ under PRD-N). This results show that the GHG emissions per unit of area increased as the irrigation water and nitrogen amounts increased. Some previous studies have reported that the main components of GHG emissions were electricity for irrigation. For example, it was found this indicate was 49.6-75.4\% for irrigated winter wheat production (Wang et el. 2016), 73\% for irrigated sugar beet production (Yousefi et al. 2014), and also $63 \%$ for soybean production (Mohammadi et al. 2013).

GHG emission was achieved by the control (FI-N) treatment $\left(42.8 \mathrm{~kg} \mathrm{CO}_{2} \mathrm{eq} \mathrm{t}^{-1} \mathrm{SRY}\right.$ and $266.6 \mathrm{~kg} \mathrm{CO}_{2} \mathrm{eq}$ $\left.\mathrm{t}^{-1} \mathrm{SY}\right)$, followed by FI-N treatment $\left(41.2 \mathrm{~kg} \mathrm{CO}_{2} \mathrm{eq} \mathrm{t}^{-}\right.$ 
SRY and $257 \mathrm{~kg} \mathrm{CO}_{2} \mathrm{eq} \mathrm{t}^{-1} \mathrm{SY}$ ) and DI-N treatment (41.1 $\mathrm{kg} \mathrm{CO}_{2} \mathrm{eq} \mathrm{t}^{-}{ }^{1} \mathrm{SRY}$ and $256.8 \mathrm{~kg} \mathrm{CO}_{2} \mathrm{eq} \mathrm{t}^{-1} \mathrm{SY}$ ), while the lowest GHG emission was found in PRD-N $\mathrm{N}_{2}$ treatment $\left(33.3 \mathrm{~kg} \mathrm{CO}_{2} \mathrm{eq} \mathrm{t}^{-1} \mathrm{SRY}\right.$ and $208 \mathrm{~kg} \mathrm{CO}_{2} \mathrm{eq} \mathrm{t}^{-1}$ $\mathrm{SY})$. As it can be seen in Table 6, the FI group required the highest total carbon inputs, which ranged from $1119.6 \mathrm{~kg} \mathrm{ha}^{-1}\left(\mathrm{FI}-\mathrm{N}_{2}\right)$ to $1291 \mathrm{~kg} \mathrm{ha}^{-1}$ (FI-N), whereas the PRD group required the lowest total carbon inputs, and the difference between the carbon inputs of these two groups were affected by deficit irrigation and nitrogen. Meanwhile, the FI-N, FI-N 1 , and FI$\mathrm{N}_{2}$ treatments returned the highest carbon outputs $9483.8,9202.5$, and $9185 \mathrm{~kg} \mathrm{ha}^{-1}$, respectively, and the
PRD group, returning the lowest carbon outputs, which ranged from $7509 \mathrm{~kg} \mathrm{ha}^{-1}\left(\mathrm{PRD}-\mathrm{N}_{1}\right)$ to $7629 \mathrm{~kg} \mathrm{ha}^{-1}$ $\left(\mathrm{PRD}-\mathrm{N}_{2}\right)$. Compared to control treatment (FI-N), the DI-N ${ }_{1}$ treatment decreased the SRY, SY and output carbon by only $5.0 \%$. On the other hand, the GHG emissions per unit of area from DI-N $\mathrm{N}_{1}$ treatment was decreased by $18.7 \%$, when compared to the FI-N treatment.

As can be seen from these results, carbon amount accumulated inside sugarbeet roots is almost 8 times more than the amount of carbon emitted in its production. In brief, sugarbeet is a plant with a high level of carbon fixation capacity.

Table 5

GHG emissions related to inputs of sugar beet production $\left(\mathrm{kg} \mathrm{CO}_{2} \mathrm{eq} \mathrm{ha}^{-1}\right)$

\begin{tabular}{|c|c|c|c|c|c|c|c|c|c|}
\hline \multirow[b]{2}{*}{ Treatments } & \multicolumn{9}{|c|}{ İnputs of sugarbeet production } \\
\hline & Electricity & $\begin{array}{l}\text { Diesel } \\
\text { fuel }\end{array}$ & Nitrogen & $\mathrm{P}_{2} \mathrm{O}_{5}$ & $\mathrm{~K}_{2} \mathrm{O}$ & $\begin{array}{l}\text { Agricultural } \\
\text { machinery }\end{array}$ & $\begin{array}{l}\text { Drip system } \\
\text { ( } \Phi 110 \mathrm{~mm})\end{array}$ & $\begin{array}{l}\text { Drip system } \\
(\Phi 16 \mathrm{~mm})\end{array}$ & $\begin{array}{l}\text { Human } \\
\text { Power }\end{array}$ \\
\hline FI-N & 2340.5 & 289.8 & 1260.8 & 214.5 & 46.2 & 35.8 & 28.5 & 361.9 & 168 \\
\hline FI-N ${ }_{1}$ & 2340.5 & 289.8 & 945.6 & 214.5 & 46.2 & 35.8 & 28.5 & 361.9 & 168 \\
\hline FI-N 2 & 2340.5 & 289.8 & 630.4 & 214.5 & 46.2 & 35.8 & 28.5 & 361.9 & 168 \\
\hline DI -N & 1769 & 289.8 & 1260.8 & 214.5 & 46.2 & 35.8 & 28.5 & 361.9 & 168 \\
\hline DI-N & 1769 & 289.8 & 945.6 & 214.5 & 46.2 & 35.8 & 28.5 & 361.9 & 168 \\
\hline DI-N ${ }_{2}$ & 1769 & 289.8 & 630.4 & 214.5 & 46.2 & 35.8 & 28.5 & 361.9 & 168 \\
\hline PRD-N & 1197.9 & 289.8 & 1260.8 & 214.5 & 46.2 & 35.8 & 28.5 & 361.9 & 168 \\
\hline PRD-N ${ }_{1}$ & 1197.9 & 289.8 & 945.6 & 214.5 & 46.2 & 35.8 & 28.5 & 361.9 & 168 \\
\hline PRD-N ${ }_{2}$ & 1197.9 & 289.8 & 630.4 & 214.5 & 46.2 & 35.8 & 28.5 & 361.9 & 168 \\
\hline
\end{tabular}

Table 6

GHG emission indicators of sugar beet production

\begin{tabular}{lccccc}
\hline Treatments & \multicolumn{2}{c}{ Areal GHG emissions } & \multicolumn{2}{c}{ Specific GHG emissions } \\
\hline FI-N & $\begin{array}{c}\text { Total GHG emissions } \\
\left(\mathrm{kg} \mathrm{CO}_{2} \mathrm{eq} \mathrm{ha}^{-1}\right)\end{array}$ & $\begin{array}{c}\text { Input Carbon } \\
\left(\mathrm{kg} \mathrm{C} \mathrm{ha}^{-1}\right)\end{array}$ & $\begin{array}{c}\text { Output Carbon } \\
\left(\mathrm{kg} \mathrm{C} \mathrm{ha}^{-1}\right)\end{array}$ & $\begin{array}{c}\text { SRY } \\
\left(\mathrm{kg} \mathrm{CO}_{2} \mathrm{eq} \mathrm{t}^{-1}\right)\end{array}$ & $\begin{array}{c}\mathrm{SY} \\
\left(\mathrm{kg} \mathrm{CO}_{2} \mathrm{eq} \mathrm{t}^{-1}\right)\end{array}$ \\
FI-N $_{1}$ & 4746.6 & 1291 & 9483.8 & 42.8 & 266.6 \\
FI-N $_{2}$ & 4431.4 & 1205.3 & 9202.5 & 41.1 & 257 \\
DI -N & 4116.2 & 1119.6 & 9185 & 37.9 & 236.5 \\
DI-N & 4174.5 & 1135.5 & 8705 & 41.1 & 256.8 \\
DI-N & 3859.3 & 1049.7 & 8961.8 & 36.7 & 229.5 \\
PRD-N & 3544.1 & 964 & 8461.4 & 35.4 & 221.1 \\
PRD-N & 3603.4 & 980.1 & 7621.7 & 40.6 & 253.6 \\
PRD-N & 3288.2 & 894.4 & 7509.6 & 37.9 & 236.3 \\
\hline
\end{tabular}

SRY: Standardized root yield; SY: Raw sugar yield

\section{Conclusions}

This paper compares the potential for environmental mitigation, including the reduction of total GHG emissions from agricultural inputs in sugarbeet production by managing irrigation and nitrogen fertilizing. This article shows that sugar beet has a higher performance than many other plants in terms of fixed carbon amount. Although, the control treatment (FI-N) required the highest carbon inputs, produced the highest carbon output value. On the other hand, compared to
FI-N, the DI-N ${ }_{1}$ treatment decreased the output carbon by only $5.0 \%$ and GHG emissions by $18.7 \%$. The results of this study indicated that although four treat-

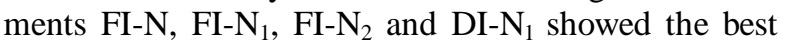
SRY performance, the environmental assessment revealed that only one treatment $\left(\mathrm{DI}-\mathrm{N}_{1}\right)$ had significantly lower environmental pollution compared with the other treatments (FI-N, FI-N 1 and FI-N ${ }_{2}$ ). Moreover, DI- $\mathrm{N}_{1}$ treatment saved $25 \%$ of irrigation water and nitrogen and $25 \%$ of electricity use in irrigation. Therefore, DI-N $\mathrm{N}_{1}$ treatment was recommended for sugarbeet production in the region studied.

\section{Acknowledgment}


This paper is derived the data regarding the production inputs and yield values of the field trial of a project (TÜBITTAK, project number:1110286), which carried out on sugar beet by Topak et al (2014) in Konya conditions.

\section{References}

Acaroğlu M, Aksoy AŞ (2005). The cultivation and energy balance of Miscanthus $\times$ giganteus production in Turkey. Biomass and Bioenergy, 29(1): 4248.

ASAE (1999). ASAE Standarts. D497.4 MAr99. Agriculture Machinery Data. pp. 350-357, ASAE 2950 Niles Rd., St. Joseph, MI, 49085-9659, USA.

Bai B, Li X, Liu Y, Zhang Y (2006). Preliminary study on $\mathrm{CO}_{2}$ industrial point sources and their distribution in China. Chinese Journal of Rock Mechanics and Engineering, 25(1):2918-2923.

Barker, T., Bashmakov, I., Bernstein, L., Bogner, J.E., Bosch, P.R., Dave, R., 2009. Technical Summary: Contribution of Working Group III to the Fourth Assessment Report of the IPCC. Cambridge Univ. Press Ch. 3.

Bolinder MA, Janzen HH, Gregorich EG, Angers DA, Vanden Bygaart AJ (2007). An approach for estimating net primary productivity and annual carbon inputs to soil for common agricultural crops in Canada. Agriculture, Ecosystems and Environment, 118: 29-42.

Chen S, Lu F, Wang X (2015). Estimation of greenhouse emission factors of China's nitrogen, phosphate and potash fertilizers. Acta Ecologica Sinica, 35: 1-19.

Devi R, Sing V, Dahiya, RP, Kumar A (2009). Energy consumption pattern of a dezentralized community in northern Haryana. Renewable and Sustainable Energy Reviews, 13(1).194-200.

Dulkadiroğlu H (2018). Türkiye'de elektrik üretiminin sera gazi emisyonlari açisindan incelenmesi. ÖHÜ Mühendislik Bilimleri Dergisi, 7(1):67-74.

Dyer JA, Desjardins RL (2003). The impact of farm machinery management on the greenhouse gas emissions from Canadian agriculture. Journal of Sustainable Agriculture, 22:59 - 74.

Dyer JA, Desjardins RL (2006). Carbon dioxide emissions associated with the manufacturing of tractors and farm machinery in Canada. Biosystems Engineering, 93(1): 107-118.

Epstein E, Bloom A (2005). Mineral Nutrition of Plants: Principles and Perspectives. 2nd Edition, Sunderland, Mass: Sinauer Associates, USA.

Göçmez G, Isçioglu A (2004). Variations in groundwater levels in Konya Closed Basin. In: Proceedings of the First National Symposium on Groundwater, General Directorate of Rural Services. Konya, Turkey; 23-24 December 2004.
Haciseferogullari H, Acaroglu M (2015). Energy Balance on Pumpkin Seed Production. Journal of Agricultural Science and Applications, 1(2): 49-53.

Handa D, Frazier RS, Taghvaeian S, Warren JG (2019). The Efficiencies, environmental impacts and economics of energy consumption for groundwater-based irrigation in Oklahoma. Agriculture, 9 (2): 27.

Jimenez-Bello MA, Royuela A, Manzano J, Prats AG, Martínez-Alzamora F (2015). Methodology to improve water and energy use by proper irrigation scheduling in pressurised networks. Agricultural Water Management, 149: 91-101.

Khan MA, Khan MZ, Zaman K, Naz L (2014). Global estimatesof energy consumption and greenhouse gas emissions. . Renewable and Sustainable Energy Reviews, 29:336-344.

Khoshnevisan B, Rafiee S, Omid M, Mousazadeh H (2013). Reduction of $\mathrm{CO}_{2}$ emission by improving energy use efficiency of greenhouse cucumber production using DEA approach. Energy 2013, 55: 676-682.

Küsters J. 1999. Energy and $\mathrm{CO}_{2}$ balance of bio-energy plants and of various forms of bio-energy. International Symposium on Nutrient Management and Nutrient Demand of Energy Plants, 6-8 July, Budapest-Hungary, 1999.

Lal R (2004). Carbon emission from farm operations. Environment International, 30: 981-990.

Mohammadi A, Rafiee S, Jafari A, Dalgaard T, Trydeman-Knudsen M, Keyhani A, Mousavi-Avval SH, Hermansen E (2013). Potential greenhouse gas emission reductions in soybean farming: a combined use of Life Cycle Assessment and Data Envelopment Analysis. Journal of Cleaner Production, 54: 89-100.

Mushtaq S, Maraseni TN, Maroulis J, Hafeez M (2009). Energy and water tradeoffs in enhancing food security: A selective international assessment. Energy policy, 37(9):3635-3644.

Nguyen TLT, Gheewala SH, Garivait S (2007). Energy balance and GHG-abatement cost of cassava utilization for fuel ethanol in Thailand. Energy Policy, 35(9):4585-96.

Niggli U, Fliessbach A, hepperly P, Scialabba N (2009). Low greenhouse gas Agriculture: Mitigation and adaptation potential sustainable farming systems 30. FAO, pp 32-33 April, Rev.

Postel S (1999). Pillars of sand: can the irrigation miracle last? New York: W.W. Norton and Company.

Pradeleix L, Roux P, Bouarfa S, Jaouani B, LiliChabaane Z, Bellon-Maurel V (2015). Environmental impacts of contrasted groundwater pumping systems assessed by life cycle assessment methodology: Contribution to the water-energy nexus study. Irrigation and Drainage, 64: 124-138. 
Qiu GY, Zhang X, Yu X, Zou Z (2018). The increasing effects in energy and GHG emission caused by groundwater level declines in North China's main food production plain. Agricultural Water Management, 203: 138-150.

Sánchez-Sastre, L.F, Martín-Ramos P, Navas-Gracia LM, Hernández-Navarro S, Martín-Gil J (2018). Impact of climatic variables on carbon content in sugar beet root. Agronomy 8, 147; 1-26.

Topak R, Süheri S, Acar B (2008). İklim-Tarımsal Kuraklık-Sulama ve Çevre Etkileşimi Yönünden Konya Havzası. Konya Kapalı Havzası Yer altı Suyu ve Kuraklık Konferansı, 11-12 Eylül 2008, Bildiriler Kitab1, Konya, 67-76.

Topak R, Uyanöz R, Ceyhan E, Acar B (2014). Damla yöntemiyle uygulanan geleneksel ve kısmi kök kuruluğu kısıntılı sulama ve kısıntılı gübreleme stratejilerinin şekerpancarının verim ve kalitesine etkilerinin belirlenmesi. TÜBITTAK Proje No:111O286.

TÜİK (2020). Türkiye İstatistik Kurumu Web sayfası. Bitkisel Üretim İstatistikleri. 2019 yılı şekerpancarı üretim

değerleri. https://biruni.tuik.gov.tr/medas/?kn=92\&locale=tr (Ziyaret tarihi: 25.09.2020).

Viala E (2008). Water for food, water for life a comprehensive assessment of water management in agriculture. Irrigation and Drainage Systems, 22: $127-$ 129.

Wang Z, Zhang H, Lu X, Wang M, Chu Q, Wen X, Chen F (2016). Lowering carbon footprint of winter wheat by improving management practices in North China Plain. Journal of Cleaner Production, 112(1): 149-157.

WWF (2014). Konya'da suyun bu günü Raporu. https://wwftr.awsassets.panda.org/downloads/konya da suyun bugnu raporu.pdf (Ziyaret tarihi: 20.9.2020).

Yousefi M, Khoramivafa M, Mondani F (2014). Integrated evaluation of energy use, greenhouse gas emissions and global warming potential for sugar beet (Beta vulgaris) agroecosy stems in Iran. Atmospheric Environment, 92: 501-505. 